\title{
Status of Beekeeping in Ethiopia- A Review
}

\author{
Kenesa Teferi* \\ College of Veterinary Medicine, Mekelle University, Ethiopia
}

Submission: November 16, 2018; Published: December 06, 2018

*Corresponding author: Kenesa Teferi, College of Veterinary Medicine, Mekelle University, Ethiopia

\begin{abstract}
Summary
Beekeeping practices is an oldest agricultural activity in Ethiopia. It is a major integral component in agricultural economy of the country. It contributes to the economy of the country directly and indirectly. Its direct contributions are collection of the honey and hive products such as bees wax, and bee colonies whereas its indirect contributions are increase in crop production and conservation of the natural environment through pollination. Despite all the potentials the subsector can offer, the apiculture in Ethiopia has suffered from under estimation of its potential and its role for socioeconomic development. The country's potential for honey and beeswax production is expected to be 500,000 and 50, 000 tons per year for honey and beeswax respectively, but only approximately about $10 \%$ of the honey and wax potential have been tapped, and the commercialization of other high value bee products such as pollen, propolis and bee venom is not yet practiced at a marketable volume, even not yet recognized.
\end{abstract}

Ethiopia ranks ninth in honey and third in beeswax production in the world. All regions of Ethiopia produce honey, but their production potential is different based on suitability of the regions for beekeeping i.e., density of bee's forages across the region is different and the techniques varies also. There are three techniques of honey production system in Ethiopia namely, traditional, transitional and modern beekeeping. The diversity of its agro-ecological region has endowed the country to have five different types of honeybees with millions of honeybees' colonies. But still the country is facing with many constraints of beekeeping such as poor harvesting practice, honey bee diseases, bee pests/predators and several other technical problems. However, beekeepers tried to minimize challenges. For example, they have abled to overcome problem of pests and predator by applying traditional and modern control method. So, this seminar focuses on the past and current status of beekeeping practices in Ethiopia.

Keywords: Bee diseases; Beekeeping; Honey and Honey Products; Pollination; Practices; Predator

Abbreviations: AAU: Addis Ababa University; ARSD: Apiculture Research Strategy Document; CSA: Central Statistical Agency; DDT: Dichloro Diphenyl Trichloroethane; EARO: Ethiopian Agricultural Research Organization; EIAR: Ethiopian Institute of Agricultural Research; ETB: Ethiopian Birr; EU: European Union; GDS: Global Development Solution; Kg: Kilogram; MASHAV: Israel's Agency for International Development cooperation; MEFCC: Ministry of Environment, Forest and Climate Change; MoARD: Ministry of Agriculture and Rural Development; OIE: World Organization for Animal Health; SNNPR: South Nation and Nationalities of People's Regional State; UK: United Kingdom; US: United States; USAID: United States Agency for International Development

\section{Introduction}

Beekeeping, also called apiculture, is management of honey bee colonies for pollination of crops and honey and other products [1]. It is an environmentally friendly and non-farm business activity undertaken by farmers and landless people. That means, it does not occupy cultivated land, requires less investment and provides quick economic benefits, besides, it being a nonpolluting intensive agricultural practice [2]. In Ethiopia, bee keeping practice had been an old age historical practice [3]. Beekeeping offers environmentally beneficial activity that can help the developing countries in alleviation of poverty and maintaining natural biodiversity [4]. It has also been contributing to rural households' income and adding to national economy in Ethiopia [5]. It plays a great role directly by providing valuable output such as honey, beeswax, queen and bee colonies, and other products such as pollen, royal jelly, bee venom and propolis, and indirectly by providing nutritional, economic and ecological security [6].
Besides that, it also provides an employment opportunity and helps in financial security as a whole [7].

Ethiopia's tremendous variation of agro-climatic conditions and biodiversity favored the existence of diversified honeybee flora and huge number of honeybee colonies [8]. The country has about 10 million bee colonies and over 800 identified honeysource plant [9]. Ethiopia is fourth largest country next only to India, China and Turkey in the world by having $6,189,329$ beehives. Presently, traditional forest and backyard, transitional and frame/modern hives practices are used in beekeeping. Out of total hives, there exist $95.73 \%$ traditional, $1.30 \%$ transitional and $3.33 \%$ frame hives [10]. About one million households are involved in honeybee's business and more than 5.15 million hived honeybee populations are found in the country [11]. As far as bee genetic resource is concerned, five statistically separable morph clusters of bees occupying ecologically different areas: 
Apismellifera adansanii exists in south and western part of the country, Apismellifera jemenitica is found in the low land areas of eastern Ethiopia, Apismellifera monticola exists in Southeast Mountain of Bale-Dinsho, northern high and mountains part of the country, Apismellifera litorea exists in southwest low lands, Apismellifera abyssinica exists in highland area of central, west and southern parts of the country [12].

Ethiopia stands ninth in the world and first in the Africa in honey production [13]. Similarly, it stands first in Africa and third in the world in beeswax production [14]. The country has the potential of producing up to 500,000 tons of honey and 50,000 tons of beeswax per annum [15]. But currently production is limited to 47,706 tons of honey and 5542 tons of beeswax [16]. Honey is produced in almost all parts of Ethiopia. However, the most important honey regions are Oromia which accounts for over $51 \%$ of the bee colonies and $38 \%$ of the honey production, followed by Amhara which accounts for about $21 \%$ of the colonies and $26 \%$ of the honey production. The Southern Nations, Nationalities Peoples Regional State, on the other hand, accounts for about $18 \%$ of the bee colonies and $18 \%$ of the honey production. while Tigray and Benshangul-Gumuz accounts for $5 \%$ and $4 \%$ of the total bee colonies, and $8 \%$ and $7 \%$ of the total honey production, respectively [17].

Beekeeping expansion has been showing low growth due to some constraints such as: improper harvesting, bee diseases, pests and predators, poisoning due to agro-chemicals and deforestation etc. [18]. The Objective of this seminar is to review about the status of beekeeping in Ethiopia including its contributions, opportunities and constraints.

\section{Contributions of Beekeeping in Ethiopia}

Beekeeping activity has important contribution economically and ecologically [19]. This sub sector has remarkable potential to contribute to employment generation, local and global market, livelihood improvement, and biodiversity conservation and helps ensuring economic advantages of women, youths \& Ethiopia's geographical position poor households. Development of the Beekeeping practices could significantly enhance crop production, food security, maintenance of plant diversity and ecosystem stability [20].

\section{Honey Production}

Honey production is one of the direct contributions of beekeeping practices [6]. In terms of economic contribution and exports commodities, honey is one of the marketed livestock products of Ethiopia. As a result, there is an increased demand for honey production [15]. Between 2000 and 2008 the total honey production in Ethiopia has increased almost by $69 \%$ from 29,000 to 42,000 tons which makes the country the leading honey producer in Africa and one of the nine largest honey producing countries in the world, accounting for $23.6 \%$ and $2.3 \%$ of the total African and World honey production, respectively [14,21]. During the years of 2009-2012, Ethiopia produced 45,250 tons of honey on average. In the years of 2013-2014, it was rose to 43,801 tons of honey [22]. Accordingly, between 2015 and 2016, it was increased to 47,706 tons [16]. Ethiopian Institute of Agricultural Research reported that currently, Ethiopia is producing approximately the same amount to during the years of 2015/2016 i.e., 47,706.10 tons.

As the honey production capacity is different from the region to region, the most important honey producing regions are Oromia (38\%), Amhara (26\%), SNNPR (18\%) and Tigray (7\%) of total honey production potential [17]. In general, the potential areas for honey production in the country include Southwestern, Western and Northwestern parts of the country [23]. These are grouped into high, medium and low potential areas. More specifically, southwestern and western areas of Kefa zone, Masha, Tepi, Dembi Dolo, Gerra, Limu, Metu, Yayu-Hurumu, and Seka Chekorsa do have high honey production potential areas covered with moderate forest trees, shrubs, bushes, herbs and cultivated crops whereas the southern, southeast and the northwest zones, and Central high lands of the country have medium potentials for beekeeping. These include most of the areas in west Gojam, south Gondar, Jimma, west Shewa, Bale, Borena and Gofa. On the other hand, many of the districts in Tigray, Wollo and Hararge and in some other parts of the country which are covered with marginal forests do have relatively low potential in honey production [24].

\section{Honey Production System}

Currently, there are three production systems of bee products are underway in Ethiopia, namely, traditional (forest and backyard), intermediate (transitional) and modern (frame beehive) system. The critical classification of each production system is based on employed technologies and probable productivity of each system [17].

\section{Traditional Forest and Backyard System}

Traditional beekeeping is the major and oldest type of beekeeping practiced in Ethiopia. It is practiced by traditionally constructed hives which are mostly cylindrical in shape (about 1-1.5 meter in length and 30-50-centimeter width) and single chamber fixed comb [25]. This type of hive can be made from wood, mud/ clay. It has no internal structures; frames were provided for the bees; the bees created their own honeycomb within the hives. The comb is often cross-attached and cannot be moved without destroying it [26].

The traditional forest honey production which is practiced in south and southwest areas of Ethiopia where there is high vegetation cover and high honey bee colonies [27]. In this case the beekeepers hang several traditional hives on trees in the dense forest mostly far away from their settlement areas. Honey hunting is common in this part of the country because of the existence of high population of wild bee colonies which make honey in hollow trees and caves.

Other method is traditional backyard system which is undertaken in safeguarded area for honeybees mostly at homestead [28]. This system of beekeeping is mainly practiced in the central, eastern and northern parts of the country where there is relatively 
low forest coverage [15]. During the year 2013-2014, the number of the traditional hives found in the country was 4,768,103 and total production from this type of hive was $39,831.7$ tons with an average production of $8 \mathrm{~kg} / \mathrm{hive} /$ season. But currently, it is estimated to be 5,706,959 hives with average production of $7 \mathrm{~kg} / \mathrm{hive} /$ season $[10,22]$. More than $95 \%$ of our beekeepers use traditional hive management practices which affect honey yield [29]. The factors responsible for low production of honey are shortage of honeybee forages, disease and pests [30].

\section{Transitional System}

A transitional system is a system between traditional and frame hive or modern system [31]. Transitional system had started in Ethiopia in the year of 1976 and the types of beehives used are: Kenya top-bar beehives, Tanzania top-bar beehive, Mud-block beehives and Ethio-ribrab hive. But Ethio-ribrab is commonly used in many parts of the country [32]. The total honey production from this type of hive was 612.7 tons with an average production

Table 1: Summary of number of beehives, production potential and average frequency of harvesting honey per year in Ethiopia [10].

\begin{tabular}{|c|c|c|c|}
\hline All types of Beehives & In number & Production (Kilograms) & Average Frequency (Harvests/Year) \\
\hline Traditional Beehives (Forest and backyard & $5,902,624$ & $42,927,921$ & 1.64 \\
\hline Intermediate/transitional Beehives & 80,832 & $2,036,969$ & 1.94 \\
\hline Modern Beehives & 205,873 & $2,741,211$ & 1.58 \\
\hline Total & $6,189,329$ & $47,706,101$ & 1.64 \\
\hline
\end{tabular}

\section{Characterization of Honey as per Regions}

Ethiopian honey differs in color, taste, quality and quantity produced [34]. Honey is produced in almost all parts of Ethiopia, with distinctive types of honey coming from different regions mainly due to the type of bee forage available in the regions [22]. The main characteristic in terms of color and taste comes from Tigray. The exceptional white color is a result of the region's high altitude and plant species that bees forage on mainly belonging to the labiates family (like sage) Becium grandiflorum locally called tebeb. But similar in terms of color, white honey is also produced in the highlands of southwest and southeast Ethiopia. Yellow honey (multi-flora honey), is also commonly produced in almost all regions of Ethiopia. It is harvested in many different parts of the country and gets its color from the various crops produced [35].

The third type of honey is referred to as Lalibela honey and is produced in central Ethiopia. Its main characteristics include its light color and fine creaminess that come from bees foraging on acacia trees. This honey variety is well known and in high demand in the domestic market. Somewhat less-appreciated varieties of Ethiopian honey are dark brown in color and bitter in taste, making them less popular for consumption. These are produced in areas with altitudes of 1,200 to 2,400 meters above sea level [35]. The other type of honey widely produced and marketed is crude red honey. Its main usefulness and popularity among beekeepers come from its low-quality requirements, because Tej houses buy it in a crude, totally unprocessed form to produce an Ethiopian type of mead [36].

The honey belt zones of Western and Southern parts of Ethiopia produce the largest quantity of honey. There are abundant of $13 \mathrm{~kg} /$ beehive/season between the years of 2013 and 2014 [22]. But currently, 2037 tons of crude honey is produced with an average of $25 \mathrm{~kg} /$ hive/season [10].

\section{Modern/Frame Hive System}

The frame hive beekeeping methods aim to obtain the maximum honey crop, without harming bees. It uses different types of frame beehives such as Zandar, Langstroth, Dadant, Modified Zandar, and Foam beehives exist in the Ethiopia [33]. These beehives differ in number of frames and size of the hive. The most commonly used frame beehive type in Ethiopia is Zandar type [32]. Between the years of 2013 and 2014, about 3,357.16 tons honey was harvested from 236,446 improved frame bee hive i.e., average production of honey $\mathrm{kg} / \mathrm{hive} / \mathrm{season}$ was 14 [22]. But currently, 2,741.2 tons is produced from 205,873 modern hives with annual average honey production of $13 \mathrm{~kg} /$ hive/season [10] (Table 1).

apicultural resources, particularly in the South Western and South Eastern zones of the country including zones like Jima, Illubabor, Bale, West Wellega, Keffa, BenchiMaji, Sidama and Gedeo zones.

Identification of the honeybee plants and assessing their abundance, their value to bees, time of blooming and flowering period have a paramount importance for practical beekeeping as well as for planning appropriate seasonal management [37]. The distribution and type of honeybee plants as well as their flowering duration vary from one place to another due to variation in topography, climate and farming practices. Hence, every region in Ethiopia has its own honey flow and dearth periods of short or long duration. The major flowering period of honey plants in Ethiopia is from September to November and April to May, after the two known rainy seasons. After the main rainy season (June to August), the highlands of Ethiopia including central and northern Ethiopia are colored with golden-yellow flowers of Bidens spp, indigenous oil crops and red violent flower of Triflouim spp. Consequently, the major honey flow period is expected from end of October to early December for central and northern parts of Ethiopia. On the other hand, in south west and south eastern parts of the country, the major honey flow period occurs during MayJune.

The main harvesting seasons are October through December for Tigray's and Lalibela honey, with an additional harvest period for Tigray's white honey in June and July; November and December for yellow honey; April and May for white honey from the southwest and southeast Highlands; and February, March, May, and June for dark-brown varieties of honey [38]. There are several

\section{Floral Calendar and Honey Harvesting Seasons}


beekeepers who are exceptionally productive to the extent of harvesting $80 \mathrm{kgs}$ per harvest through harvesting twice in a single harvest season at Addis Ababa. There are also farmer beekeepers who managed double harvesting in a single harvest season both in Tigray and Oromia.

\section{Domestic Market}

In Ethiopia high portion of honey is sold for income generation. The domestic honey market starts at the smallholder bee keeper's level, who majorly sells crude honey to collectors in the nearest town/village markets [39]. Beekeepers of the country sell the largest proportion of their honey during harvest at low price mainly to meet their demand for cash to pay taxes, debts and other social obligation. Similar authors notified that, the price of honey is also governed by different factors such as distance from market (28\%), quality of honey (25\%), consumers 'preference $(20 \%)$, color of honey $(15 \%$,), and test of honey (12\%). About $10 \%$ of the honey produced in the country is consumed by the beekeeping households. The remaining $90 \%$ is sold for income generation and of this, it is estimated that $70 \%$ is used for 'tej' brewing.

Honey price is differing by region and type of honey. The most expensive is Eastern Tigray's white honey, where the current retail price is ETB $170.00 / \mathrm{kg}$. Lower retail prices (of around ETB $60-90.00 / \mathrm{kg}$ ) are observed for other varieties of white honey, depending on the area and the honey 's characteristics. The retail prices for yellow honey are around ETB 50-60.00/kg, while the least expensive red honey is sold at a price of around ETB 45-50/kg [40]. Domestic honey consumption is increasing due to highly increasing demand for tej, increased consumption of processed table honey in most urban areas and increased demand for honey in the local industries [41]. The total volume of domestic consumption in 2007-2011 was 163,257.42tons, out of which $146,931.67$ tons was domestic consumption [40]. Recently, country's domestic honey market is estimated to be 42935 tons out of total 47,706,101 tons [15].

\section{Beeswax Production}

Bees wax is valuable byproduct of beekeeping that serves beekeepers as source of income. It does not require careful packaging, easy to store and transport [1]. Beeswax is used to produce light candle particularly in the Orthodox churches. In Ethiopia in the year of 2011-2013, about 5000 tons were produced on an average annually. But during the years of 2014-2016, it was increased to 5458.3 tons. The currents annual beeswax production is estimated at 5700 tons. This makes Ethiopia the fourth largest beeswax producing country in the world after China, Mexico and Turkey [42].

\section{Crop Pollination}

Honeybees (Apismellifera litorea) being primary pollinating agents help to pollinate flowers, horticultural crops and vegetables worldwide [43]. The contribution of honeybee pollination to crop production and quality has been estimated to be more than the value of honey and wax production [44]. Because bees contribute about 200 billion USD per annum for the global economy. But this golden service of bees is not recognized in Ethiopia and even in Africa as well. For many crops, pollination may be one of the best ways of improving crop production [45]. In Ethiopia, pollination by honeybees had increased the seed yield of Niger (Guizotia abyssinica) by about 43\% [46] and Onion (Allume cepa) by twofold [47]. Therefore, honeybees' pollination has brought about significant economic contribution in crop production [48] and human nutrition security [49]. Thus, investment in the apiculture sector means diversifying income source, enhancing agricultural yield of smallholder farmers, and creating employment opportunities for the youth, women and conserving biodiversity, mitigating climate change and improves exchange of foreign currencies. Overall, investing in the apiculture sector is meant strengthening sustainable socioeconomic development of the society.

\section{Export Market}

Beekeeping products play significant role in the development of national economy. Honey and other apiculture products such as beeswax, propolis, pollen, royal jelly and bee venom are among the growing export commodities with good potential in many African countries [50]. The developing countries get a chance of money exchange with honey and other apiculture products. Ethiopia exports honey to the countries such as Sudan, Norway, Saudi Arabia, UK, Yemen, Japan, USA and. For the first time Ethiopia exported honey to European country, U.K. was 30 tons in 2008 others [51]. Between the years of 2008-2011, Ethiopia exported 7,068 tons $\mathrm{kg}$ of honey and 6,752 tons of beeswax. As it was increasing from time to time, it reached 4252.8 tons of honey in the year 2011-2016. Currently, the export had reached up to 900 tons per annum [51,52]. The beeswax price at the domestic market is mostly higher than the international beeswax price which makes beeswax export less profitable in Ethiopia.

\section{Source of Immediate Cash Income}

Beekeeping plays significant role in supplementing the annual income. Honey production and value addition to its products are vital factors in sustainability of livelihood of poor people [15]. In Southwest Ethiopia, production from honey can reach 100-200 kg per year and fetches price per kg of 8-10 Birr. Thus, the potential annual income from honey can reach 800-2000 Birr [53]. An average of 420 million ETB was obtained annually from the sale of honey. In Ethiopia, the total annual gross value of 2.20 billion ETB and 0.15 billion of ETB was earned from honey and bees wax respectively [54].

\section{Job Opportunities}

Beekeeping practices create job opportunities for landless men and women for their livelihood as it needs low capital to start [55]. It could also be observed that many people (intermediaries and traders) participate in honey collection and retailing (at village, district and zonal levels). Hundreds of honey processors are engaged in Tej brewing and exporters are also flourishing. It can also serve as job opportunities to local carpenters and organized youths in construction of beehive. 


\section{Environmental Protection}

Beekeeping is a non-destructive activity that could be employed in the conservation of biodiversity [56]. Bees provide numerous benefits in maintaining sustainable natural environment. These are needed for the pollination of many cultivated crops and maintaining biodiversity. More plantations for supplying pollen and nectar need to be encouraged. Thus, many plants are conserved and protected from destruction in this way [57].

\section{Opportunities of Beekeeping Practices in Ethiopia}

\section{Agro-Ecology of Beekeeping in the Country}

Existence of diverse flowering plants: Ethiopia has a potential in beekeeping because of growing of different vegetation and crops which are a good source of nectar and pollen for honey bees in the country [58]. Large and diverse botanical resources combined with suitable climatic conditions make it conducive for the beekeeping business [59]. In Ethiopia, there are about 7000 species of flowering plants upon which the bees feed and collect important raw materials necessary to make honey and other hive products [15]. Due to this suitable natural environment, around 10 million honey bee colonies exist in the country.

\section{Diverse agro-Climatic Conditions}

The existence of diverse ecologies and agro climatic conditions favors the movement of bees from one ecological area to the others, which enable them to escape harsh periods [60]. In Ethiopia there are five types of honeybees found in different ecological namely: Apismellifera adansanii exists in south and western part of the country, Apismellifera jemenitica is found in the low land areas of eastern Ethiopia, Apismellifera monticola exists in Southeast Mountain of Bale-Dinsho, Apismellifera litorea exists in southwest low lands, Apismellifera abyssinica exists in highland area of central, west and southern parts of the country. There are millions of honeybee colonies which are found in different agro-ecological regions of the Ethiopia [61]. In general, the density of honeybee colonies is more in high biomass areas of the west and northwest parts of the country as compared to the low biomass and moisture stress areas of the eastern region [15].

\section{Market Opportunities and Increasing Demand for Bee- keeping Products}

Ethiopia has a good export market opportunity for bee products like honey and bees wax. Demands of bee products are enormously increasing from time to time at an alarming rate. The healthy condition of bees and production of organic honey are the basically high in demand. Low level of pesticide applications creates opportunity for organic beekeeping development.

\section{Major Constraints of Beekeeping in Ethiopia}

\section{Absconding and Migration}

Honeybee colonies abandoned and migrated from their hives at any season of the year for different reasons. The incidence of absconding of bee colonies is high traditional hives. The main reasons for absconding and migration of bee colonies are lack of forage, incidence of pests and predators, during harvesting, sanitation problem, bad weather condition, and bee diseases, drought, overgrazing, deforestation and shortage of water [62-64].

\section{Honey Bees Pests and Predators}

Small hive beetle (Aethina tumida): Small hive beetles infest bee colonies (species of the genera Apis and Bombus and stingless bees). The adult beetle is attracted to bee colonies to reproduce, although it can also potentially survive and reproduce independently in other natural environments, using other food sources [65]. In Ethiopia, the small hive beetle was reported in the maize and coffee growing zones of Oromia regional state [66] (Figure 1).

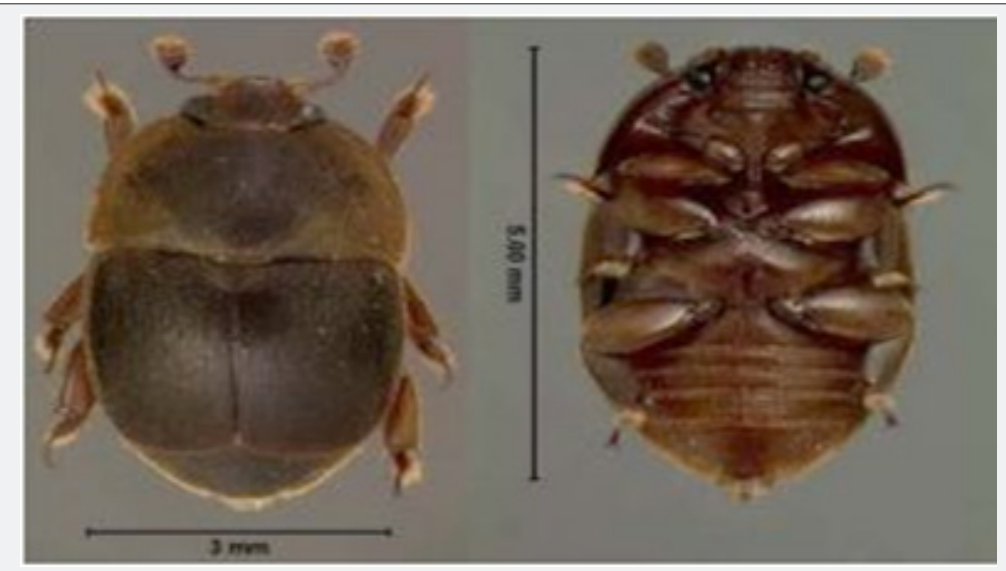

Figure 1: Small hive beetle (Aethina tumida).

\section{Bee Lice (Braulacoeca)}

The bee louse, or braula (Braulacoeca), is a wingless fly that does not damage or parasitize any stage of the honeybee life cycle. However, adults do steal food from bees and larvae. In large numbers; they may reduce food availability and impair egg- laying ability of queen [67]. Infestation of lice in honey bees had been reported from the western region of Shoa, zone of Oromia regional state [68]. In Tigray regional state, and Amhara region, louse infestation was reported to infest brood and adult bees [69] (Figure 2). 


\section{Journal of Dairy \& Veterinary Sciences}

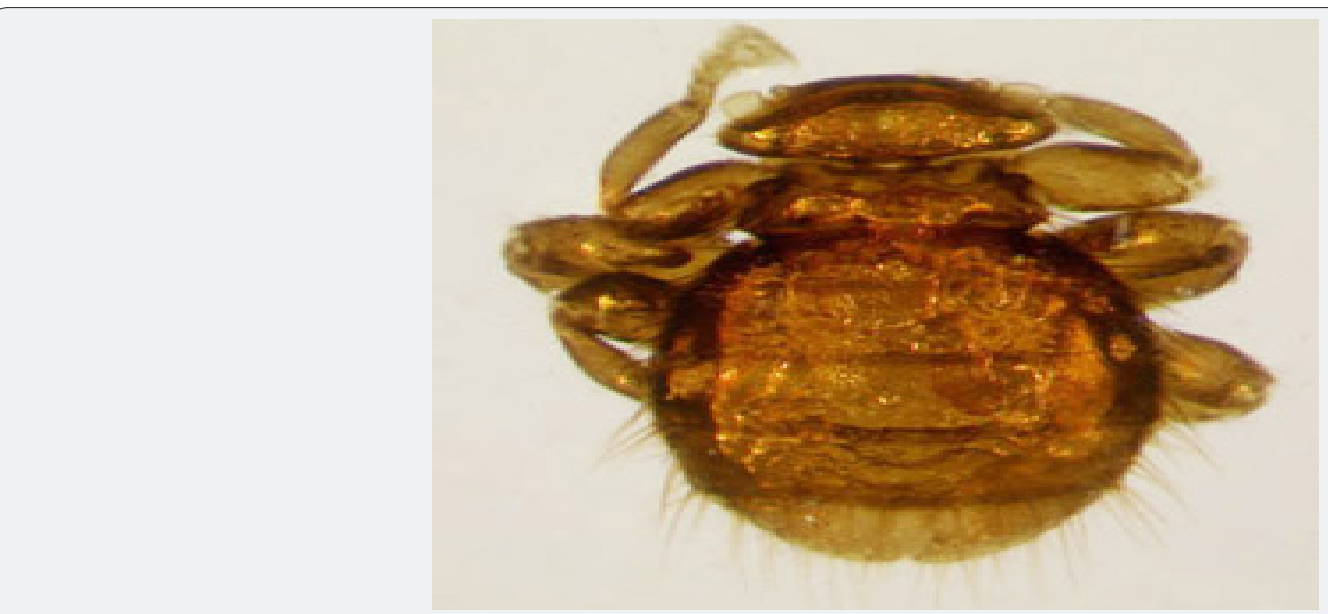

Figure 2: Bee lice (Braulacoeca).

\section{Ants (Dorylus fulvus)}

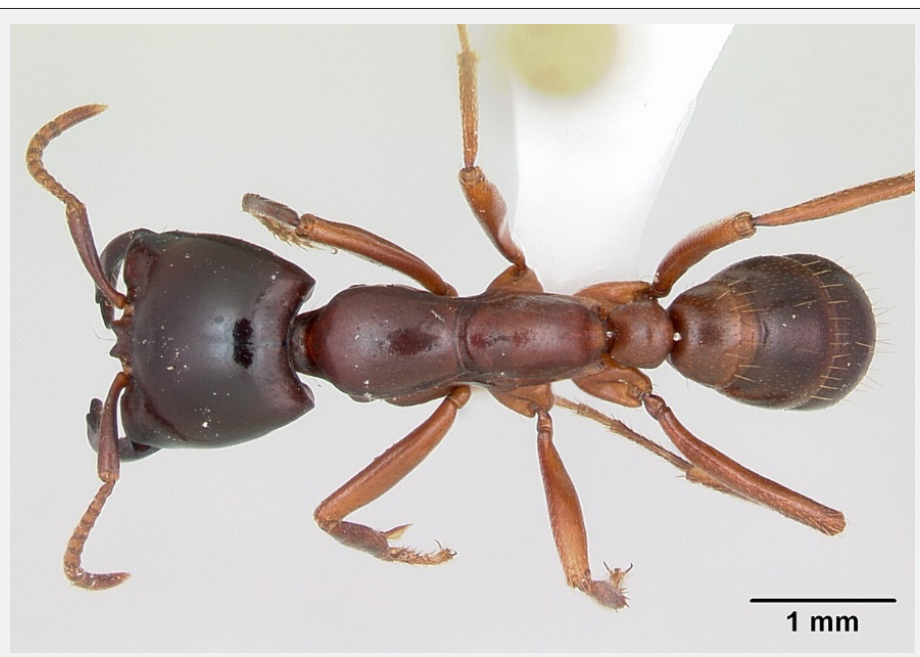

Figure 3: Ants (Dorylusfulvus)

Ants (Dorylus fulvus) are one of important honey bees' enemies [70]. In Tigray, Amhara, SNNPR and Oromia regional states in Jimma zone, bee keepers consider it a serious problem [71]. Ants cause severe economic loss in honey production by

\section{Wax moths (Gallera mellonella)}

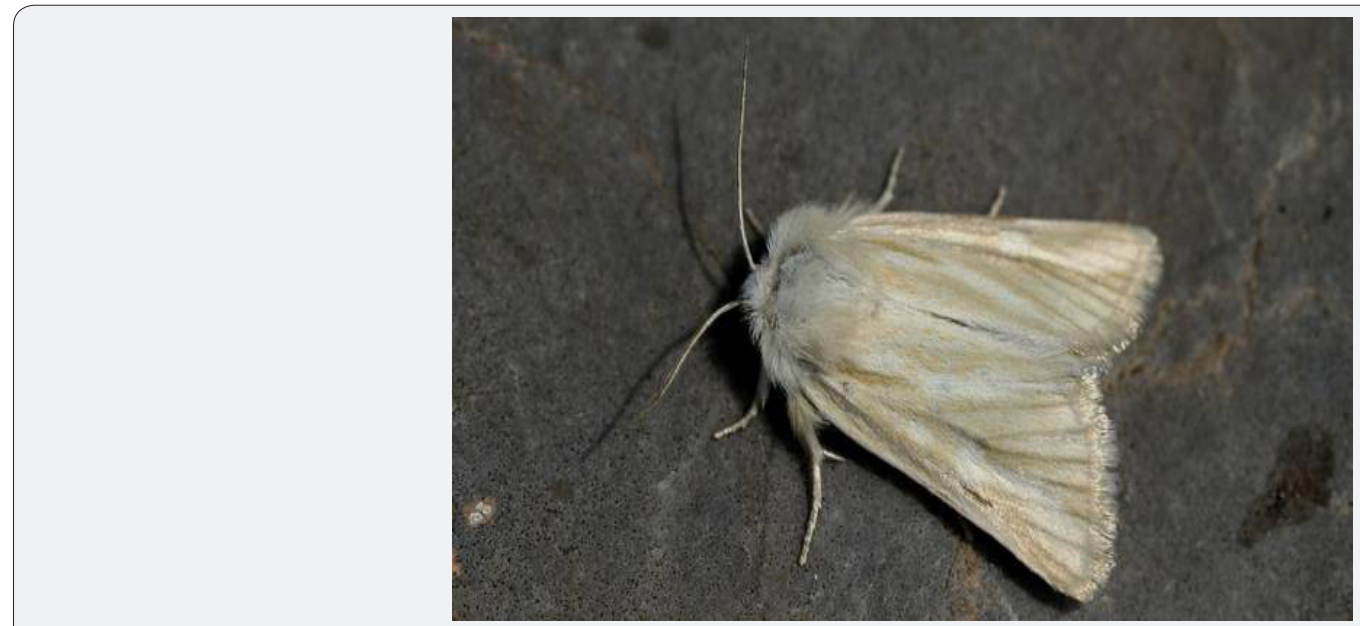

Figure 4: Wax moths (Galleramellonella).

killing bees, rob their products [72]. They feed on honey, brood, bee wax, pollen and lead to absconding of bees and destroying the entire bee colony [73]. Bees are the victim of its attack leading to loss of honey [74] (Figure 3). 
Wax moths are serious pests causing loss in production of bee wax. They feed on pollen, cast skins and cocoons, but don't destroy bee colonies. The wax moth pests infest stored equipment's and weakens colony. The wax moth affecting honey bees had been reported in the South and South West of parts of Ethiopia [75]. There was also similar report in the Tigray regional state [76] (Figure 4).

\section{Mice}

It causes damages in hives during drought periods. They can destroy large areas of comb to build their nests. A strong colony which has abundant bees to cover the entire comb in the hive will not allow mice to build nests.

\section{Predatory Birds}

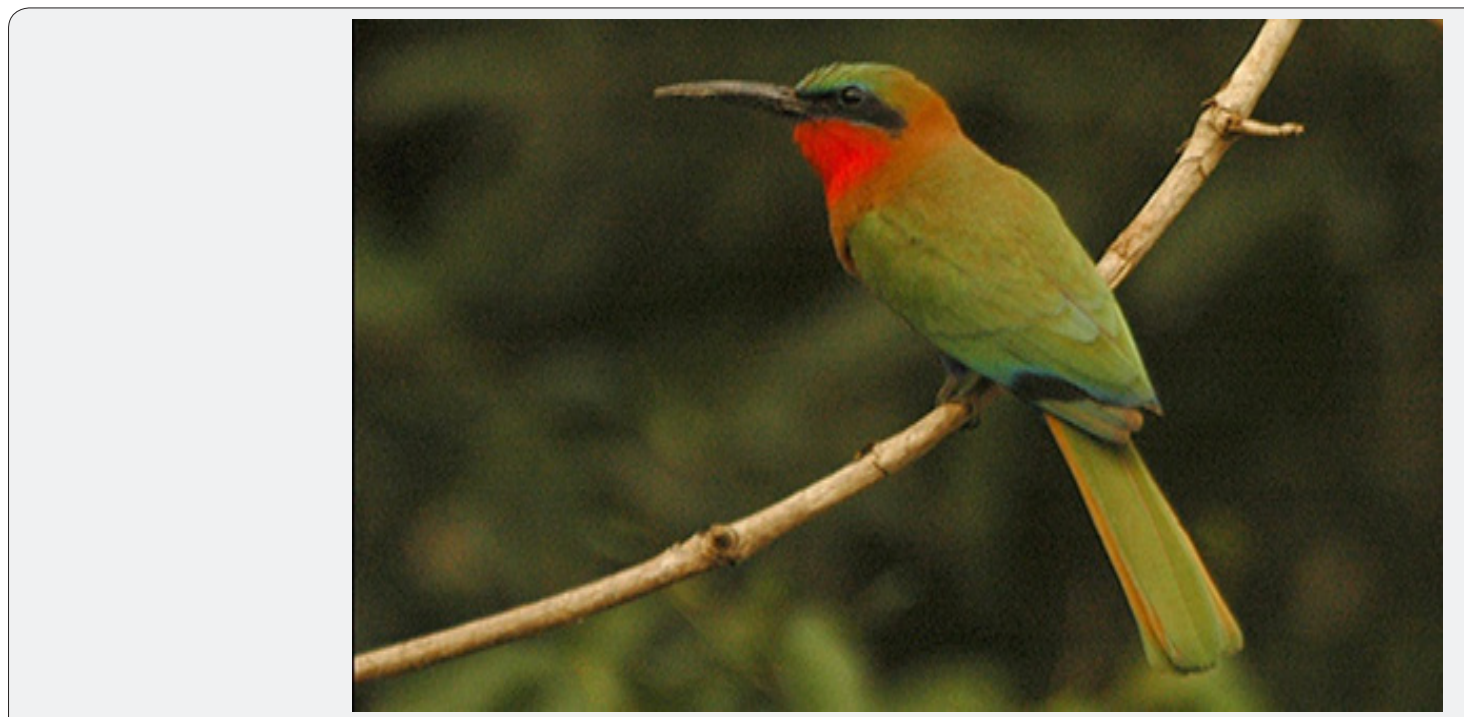

Figure 5: Red-throated Bee-eater (Merops bulocki).

Bee-Eating Birds are widely distributed, and many beekeepers regard them as serious pests [77]. "Avi base" bird species found in Ethiopia are Red-throated Bee-eater(Merops bulocki), Little Bee eater(Merops pusillus), Blue-breasted, Bee eater (Merops variegatus), Swallow tailed Bee eater(Meropshirundines), Somali Bee-eater(Merops revoilii), White-throated Bee-eater(Meropsalbicollis), Green Bee-eater(Merops orientalis), Blue-cheeked Bee-eater(Meropspersicus), Madagascar Bee-eater(Merops superciliosus), European Bee-eater(Meropsapiaster), Northern Carmine Bee-eater(Merops nubicus) [78]. The bee-eaters are a uniform group, morphologically and are highly aerial. They take offstrongly from perches, fly directly without undulating, and can change directions quickly [79] (Figure 5).

\section{Diseases}

\section{Chalk Brood Diseases}

Chalkbrood is a fungal disease of the honeybee larvae caused by Ascosphaeraapis. It rarely destroys a colony but can prevent normal population build-up. In Ethiopia the survey on chalkbrood diseases was started in the year of 2000, and the existence of the diseases was reported in 2001 around the Holeta research areas. The overall report of the prevalence of this disease in est Shoa, Arsi, east Shoa and north Shoa was 56.49\%, 24.5\%,13.74\%, 7.63\% and $9.92 \%$ respectively. In Ethiopia, the geographical distributions of chalkbrood disease in honey bee were recorded [80]. The study reported an infection rate of $37.12 \%, 19.89 \%$, and $17.93 \%$ and distribution rate of $87.50 \%, 56.56 \%$ and $33.33 \%$ in Amhara, Oromia and Benshangul-gumuz.

\section{Nosematosis}

Nosema is caused by protozoan parasite namely Nosemaapisand Nosemaceranaethat infect the intestinal tract of adult bees and reduces queen performance. It is widespread and causes heavy losses in honey production, and severely weakens colonies [81]. Diagnosis made on 152 colony bees in field and laboratory at Addis Abeba reported prevalence rate of 53.3\% [82]. In Ethiopia nosema was also reported from different regions with varying prevalence rate such as 58\% in Oromia, $60 \%$ BenishangulGumuz and 47\% in Amhara region [83]. Similar survey conducted in 58 districts of Oromia, Amhara, Southern Nations and Nationality and Peoples (SNNP), Tigray, Gambella, Benishangul -gumuz, Somale regional state of Ethiopia, Nosemaapis were identified the species causes nosematosis with $37.3 \%$ of infection rate [84].

\section{Amoeba}

Amoeba is disease of honey bees caused by a single celled parasite Malpigh amoeba mellificae. The parasite affects malphigian tubules thus shortening the life cycle of bees. Survey conducted in the year of 2000, Amoeba was reported in South and South parts of the Ethiopia. Diagnosis made on honey bees in field and laboratory at Addis Ababa reported a prevalence rate of $73 \%$ of amoeba infestation. The diseases were also reported with high prevalence rate in different regional state of Ethiopia such as; Oromia region with prevalence rate (88\%), Amhara region (95\%) and $60 \%$ in Benishangul- Gumuz. 


\section{Varroosis}

Varroosis is a disease of honey bees which is caused by a mite known as Varroa destructor. The mite is an ectoparasite of adults and brood of honey bees. It spreads by direct contact from adult honey bee and by the movement of infested honey bees, bee brood, bee products and infected apicultural equipment. Varroa mite has a major impact on apiculture industry and untreated colonies of Apismellifera will collapse within two years of infection. The mite had been reported in Tigray regional state in the district of Aferom and Endamehoni [85].

\section{Poisonous Plants}

A red color flower from a plant locally called Ababbo Diima had been reported to kill worker bees during their flowering stages in Ilubabor zone of Oromia region [86]. Plant species belonging to families of Ranuculaceae, Solanaceae, Acanthacae, Euphorbiaceae and Phytolacaceae were also reported to act as poisons to bees in Northern regions of Ethiopia [87]. Similarly, the nectar or pollen of poisonous plants such as Bahirzaf (Eucalyptus spp), Simiza (Uustitiaschemperina) Cassia siamea, Croton macrostachyus, Aloe brahana, Zizyphus mucronata, Phytolacca dodecandra and Susbania species had been reported in Amhara region to be toxic to bees and the honey produced from their nectar are toxic to humans [88]. In addition, Euphorbia cottinifoliais had been known to kill honeybees in SNNPR [89].

\section{Technical Constraints}

\section{Application of agrochemicals}

Bee poisonings initially affect the beekeepers who are trying to derive their income from the bees. The use of chemicals and pesticides in controlling crop pests, weeds, tsetse fly

Table 2: Honey bee pests and predators control methods [18,26]. and mosquitoes brings damages to the colony, as well as the contamination of hive products. In Ethiopia, insecticides and herbicides had been reported as major causes of the death of the colony and absconding in Amhara region.

\section{Poor Harvesting Method}

The destruction of broods while harvesting the honey and slows regeneration of bee population. Eventually, it ends up with the declining of the colony. This is common in traditional hive where every comb is used for both laying egg by the queen and honey/pollen storage by the workers [90].

\section{Deforestation}

Shortage of bee forage, lack of land use policy and high demand for farmlands for crop production and livestock grazing are the biggest hindrances in bee keeping thereby it creates deforestation, soil erosion and irreversible ecological degradation. Moreover, destroying of forestland for expansion of farmland could trigger a reduction of honey producing floras and foraging areas. The cutting off nectar and pollen producing tree species in many areas makes it difficult to maintain bee colonies [91]. Shortages of bee forage cause the honeybee colony to abscond. Lack of feed, honey bee pests and drought are the main problems that cause absconding of honey bees [92].

\section{Methods of Controlling Honey Bee Predators and Pests}

Beekeepers practice different prevention methods to overcome problems of pests and predators of honey bee. They use numbers of traditional control methods base up on the type target enemies either individually or in combination with modern control methods (Table 2).

\begin{tabular}{|c|c|c|}
\hline $\begin{array}{l}\text { Major Honey Bee Pests and } \\
\text { Predators }\end{array}$ & Traditional Control Methods & Modern Control Methods \\
\hline Ants & $\begin{array}{l}\text { Frequent smoking, plastering hive stand with plastic, using local olum Africana/euca- } \\
\text { lyptus leaf for fumigation, daily follow up and using hot water, using ash. }\end{array}$ & $\begin{array}{l}\text { Benzene, DDT, malathoin } \\
\text { Smooth Iron sheets }\end{array}$ \\
\hline Hive beetles & Scavenge poultry, narrow the hive entrance, Seasonal management and cleaning & DDT and Roach killer \\
\hline Birds & Placing the seeming image of human near the hives using cloth, plastics, Using stone. & - \\
\hline Mites & Burning. Killing, removing their home. & - \\
\hline Wax moth & Remove old comb, strengthen the colony, seasonal management, daily supervision & - \\
\hline Bee lice & $\begin{array}{l}\text { Smoking/fumigating the hive with materials like tobacco, dung, grass, etc, making the } \\
\text { colonies strong, giving additional food for weaken colonies. }\end{array}$ & - \\
\hline Lizard & Removing their nesting site & - \\
\hline Mites & Burning. Killing, removing their home. & - \\
\hline Spider & Removing spiders web, Cleaning, follow up & DDT and roach killers \\
\hline Hamagot & Fencing with thorny plants, putting barriers & - \\
\hline Wasps & Cleaning hive & - \\
\hline Honey badger & $\begin{array}{c}\text { Use of chasing dogs, use of "wotmed" to kill, fencing the apiary site with strong fence, } \\
\text { hanging hives by rope on long trees }\end{array}$ & - \\
\hline
\end{tabular}

\section{Conclusion and Recommendation}

Generally beekeeping is an old agricultural practice in Ethiopia. About one million households are involved in honeybee's business. It is promising off-farm enterprise, which contributes to country's economy. Ethiopia has production potential of 500000 and 50000 tons of honey and beeswax respectively [93-95]. However currently, 47,706 tons of honey and 5700 tons beeswax 
are produced. The honey production is increasing relatively from time to time, because of increased demand at market level (domestic and export). The honey production capacity is not equal among the regional states. Potential honey producing regions are Oromia, Amhara, SNNPR and Tigray respectively. Besides that, there are two major honey harvesting periods, November to December in the lowlands and midlands and from April to May in the highlands. Honey production is being per formed in three major ways: Traditional (forest and backyard), transitional and modern ways. Of these traditional system accounts for about $90 \%$ of honey produced in the country. Country's diverse agroecology which includes many flora and fauna and diverse agro climates favors the country to possess a huge number of honeybee colonies estimated to be 10 million with five different categories of honeybee. Despite country's suitable environment, there are several bottlenecks /constraints for beekeeping. Among of these are poor honey harvesting, diseases, pests, predators, poisonous plants, agrochemicals and deforestation are major ones.

Based on the above conclusions, the following recommendations are forwarded:

a. Beekeepers should be made aware regarding proper harvesting method which avoid destruction of the colony and absconding.

b. Encourage the bee keepers to plant more trees and to make them aware about devastating effects of deforestation.

c. Beekeepers should be made aware about the harmful effects of honeybees' pest / predators, bee diseases, use of agrochemicals, poisonous plants affecting honey bees and their control measures.

\section{Acknowledgement}

First, I would like to express my heart full gratitude to my advisor Prof. Kuldip Singh for providing critical comments and suggestions besides spending lots of his valuable time in editing this seminar paper. Lastly, I would like to express my heartfelt acknowledgement to my father Teferi Abdeta and my mother Kibitu Mirkana for their financial support and encouragement.

\section{References}

1. Bradbear (2009) Nonwooden Forest Products. Bees and their role in forest livelihoods. Food and Agriculture Organization of the United Nations. Rome, Italy.

2. Conrad R (2007) Natural Beekeeping: Organic Approaches to Modern Apiculture. Chelsea Green, London, UK.

3. Tessega B (2009) Honeybee Production and Marketing Systems, Constraints and Opportunities in Burie District of Amhara Region, Ethiopia. MSc Thesis (Animal Production) Bahir Dar University. pp. 131.

4. MASHAV (2016) Israel's Agency for International Development Cooperation: Modern Apiculture Management.

5. Gemechis L (2015) Honey Production and Marketing in Ethiopia. American Journal of Life Science, 3(1): 42-46.

6. ARSD (2000) Apiculture Research Strategy Document: Ethiopian Agricultural and Research Organization, Addis Ababa, Ethiopia.
7. Abebe W, Puskar R (2011) Beekeeping Sub-sector Challenges and Constraints in Atsbi Wemberta District of Eastern Zone, Tigray Region, Ethiopia. Journal of Agricultural Extension and Rural Development 3(1): 8-12.

8. Nuru A (2007) Atlas of Pollen Grains of Major Honeybee Flora of Ethiopia. Addis Ababa, Ethiopia. pp. 152.

9. Kebede N, Subramanian P, Gebrekidan M (2011) Physicochemical Analysis of Tigray Honey: An Attempt to Determine Major Quality Marker of Honey. Chemical Society of Ethiopia, Addis Ababa, Ethiopia.

10. CSA (2016/17) Central Statistical Agency: Agricultural Sample Survey 2016/17. Report on livestock and livestock characteristics. Addis Ababa, FDRE, Ethiopia.

11. Adgaba N, Al-Ghamdi A, Shenkute G, Ismaiel S, Al-Kahtani S, et al. (2014) Socio economic Analysis of Beekeeping and Determinants of Box-hive Technology Adoption in the Kingdom of Saudi Arabia. The Journal of Animal and Plant Sciences 24(6): 1876 -1884.

12. Amsalu B (2004) Beekeeping in South and South Western Ethiopia. Journal of Bees for Development, 73: 8 .

13. Tesfaye B, Genet D, Temaro G (2017) Assessment of Honeybee Enemies (Pests and Predators) in Bale Zone, Southeastern Ethiopia. Journal of Agricultural Extension and Rural Development, 9(4): 53-61.

14. MoARD (2003) Ministry of Agriculture and Rural Development: Honey and Beeswax and Marketing Plan, Addis Ababa, Ethiopia.

15. EIAR (2017) Ethiopian Institute of Agricultural Research: Livestock and Fisheries Research Strategies. Poultry, Fisheries, Apiculture and Sericulture. Addis Ababa, Ethiopia, pp. 153-224.

16. FAO (2017) Food and Agriculture Organization: Livestock Primary.

17. AAU (2015) Addis Ababa University: Strategic Plan to Develop a Globally Competitive Honey Industry in Ethiopia. Addis Ababa, Ethiopia.

18. Tesfaye B, Begna D, Eshetu M (2017) Beekeeping Practices, Trends and Constraints in Bale, South Eastern Ethiopia. Journal of Fisheries and Livestock Production, 5: 215.

19. Ajabush D (2018) Review of Economic and Ecological Importance of Bee and Bee Products in Ethiopia. Journal of Animal Husbandry and Dairy Science, 2(2): 18-26.

20. Apimondia International Symposium (2018) The Role of Bees in Food Production. Apimondia International Symposium, Addis Ababa, Ethiopia.

21. FAO (2008) Food and Agricultural Organization: Livestock Primary.

22. CSA (2013/14) Central Statistical Agency: Agricultural Sample Survey 2013/2014. Report on Livestock and Livestock Characteristics. Addis Ababa, FDRE, Ethiopia.

23. Gezahegn T (2001) Marketing of Honey and Beeswax in Ethiopia: Past, Present and Perspective Futures. In Proceedings of the Third National Annual Conference of the Ethiopian Beekeepers Association (EBA), Addis Ababa, Ethiopia, p. 78-88.

24. Fenet B, Alemayehu O (2016) The significance of Honey Production for Livelihood in Ethiopia. Journal of Environment and Earth Science, 6(4): 46-53.

25. MoARD (2007) Ministry of Agriculture and Rural Development: Annual Report. Addis Ababa, Ethiopia.

26. Teklu G (2017) Enhancing Rural Food Security and Conserving Natural Environment through Improved Beekeeping in Asano Koto Watershed, Ethiopia. European Journal of Agriculture and Forestry Research, 5(1): $35-48$.

27. Fikru S (2015) Review of Honeybee and Honey Production in Ethiopia. Journal of Advanced Animal Science, 5(10): 1413-1442.

28. Hackett J (2004) Bee Benefits to Agriculture. Agricultural Research Magazine, USA. 
29. Workeneh A (2007) Financial Benefits of Box Hive and the Determinants of its Adoption in Selected District of Ethiopia. American Journal of Economics, 1(1):21-29.

30. Wongelu E (2017) Pre-Scaling up of Transitional Locally Made Beehive Technology Package in West Shoa Zone, Oromia Region, Ethiopia. Journal of Agricultural Economics, Extension and Rural Development, 5(2): 600-605.

31. Sisay G, Eyassu S, Amsalu B (2012) Physicochemical Properties of Honey Produced in the Homesha District of Western Ethiopia. HaramayaUniversity. Journal of Apicultural Science, p. 33-40.

32. Abebe (2017) Characterization of Beekeeping System and Evaluation of Honey Quality in Tehulederie District of South Wollo Zone, Amhara Region, Ethiopia. Bahir Dar University, College of Agriculture and Environmental Sciences Graduate Program, Bahir Dar, Ethiopia.

33. Ayalew K (2001) Promotion of Beekeeping in Rural Sector of Ethiopia: Proceedings of Third National Annual Conference of Ethiopian Beekeepers Association. Addis Ababa, Ethiopia, p. 52-58.

34. Beyene T, David P (2007) Ensuring Small Scale Producers in Ethiopia to Achieve Sustainable and Fair Access to Honey Markets. Paper Prepared for International Development Enterprises (IDE) and Ethiopian Society for Appropriate Technology, Ethiopia. p. 64.

35. Miklyaev M, Glenn P, Jenkins Richard R, Barichello (2013) Honey production in Ethiopia: A Cost Benefit Analysis of Modern versus Traditional Beekeeping Technologies.

36. Agonafir J (2005) Strategic Intervention Plan on Honey and Beeswax Value Chains. SNV Support to Business Organizations and Their Access to Market (BOAM) p. 1-36.

37. Gichora M (2003) Towards Realization of Kenya's Full Beekeeping Potential. A case Study of Baringo District. Ecology and Development Series No.6, 2003. Cuvillier Verlag Gottingen, Germany. pp. 155-158.

38. GDS (2009) Global Development Solution: Integrated Value Chain Analysis for Honey and Beeswax Production in Ethiopia and Prospects for Exports. The Netherlands Development Organization (SNV).

39. Assefa A (2009) Market chain analysis of honey production: in Atsbi Wemberta District, Eastern Zone of Tigray National Regional State. A Thesis Submitted to College of Agriculture Department of Agricultural Economics, School of Graduate Studies. Haramaya University, Ethiopia.

40. USAID (2012) United States Agency for International Development/ Ethiopia: Cost-Benefit Analysis of the Grad Honey Value Chain. Cambridge, USA.

41. Assefa M (2011) Pro-Poor Value Chains to Make Market More Inclusive for the Rural Poor: Lessons from the Ethiopian honey value chain. Danish Institute for International Studies, Copenhagen, Denmark. p. 35-50.

42. Sahle H, Enbiyale G, Negash A, Neges T (2018) Assessment of Honey Production System, Constraints and Opportunities in Ethiopia. Pharmacy and Pharmacology of International Journal, 6(2): 23796367.

43. Porter and Penny (2017) Advantages and Disadvantages of Honeybees Science.

44. Shrestha B (2004) Honeybees and Environment. Agriculture and Environment. Gender Equity and Environment Division. Ministry of Agriculture and Cooperatives, HMG, Nepal, India, p. 1-8.

45. Goodwin G (2012) Pollination of Crops in Australia and New Zealand. Rural Industries Research and Development Corporation Publication No. $12 / 059$

46. Admasu A, Nuru A (2002) Effect of Honeybee Pollination on Seed Yield and Oil Content of Niger (Guizotiaabyssinica): Proceedings of the First National Conference of Ethiopian Beekeepers Association, Addis Ababa, Ethiopia, p. 67-73.
47. Debisa, Adimasu A, Gizaw, E, Amsalu B (2008) Effects of Honeybee Pollination on Seed Allium cepa: HBRC, Ethiopia. Ethiopian Journal of Animal Production, 8(1): 79-84.

48. Gallai N, Salles J, Settle J, Vaissiere B (2009) Economic Evaluation of the Vulnerability of World Agriculture Confronted with Pollinator Decline. Ecological Economics, 68: 810-821.

49. Ellis A, Myers S, Ricketts T (2015) Do Pollinators Contribute to Nutritional Health? PLoS ONE 10(1): e114805.

50. Paulos D (2012) Ethiopian Honey: Assessing International Markets with Inclusive Business and Sector Development.

51. Demisew (2016) Beekeeping in Ethiopia.5thApiExpo Africa, Kigali, Rwanda.

52. FDRE (2016) Federal Democratic Republic of Ethiopia: The $9^{\text {th }}$ National Monitoring Plan for Residues in Honey from Ethiopia. Ministry of Livestock and Fisheries (MoLF), the Livestock Health and Feed Regulatory Sector, Addis Ababa, Ethiopia.

53. Adilo M, Woldemariam T, Yadessa A (2005) Counting on Forests: NonTimber Forest Products and their Role in the Households and National economy in Ethiopia. Proceedings of the $8^{\text {th }}$ Annual Conference of Agricultural Economics Society of Ethiopia, Addis Ababa, Ethiopia, pp. 179-196.

54. MEFCC (2015) Ministry of Environment, Forest and Climate Change: Study of Causes of Deforestation and Forest Degradation in Ethiopia and the Identification and Prioritization of Strategic Options to Address those. Final Report. Addis Ababa, Ethiopia.

55. Abadi B, Abebe A, Delenasaw Y (2016) Community Perception on Beekeeping Practices, Management, and Constraints in Termaber and Basona Werena districts, Central Ethiopia.

56. Gemechis L, Kibebew W, Amsalu B, Desalegn B, Admassu A (2012) Apiculture Research Achievements in Ethiopia, Oromia Agricultural Research Institute, HBRC, Ethiopia.

57. FAO (2009) Food and Agricultural Organization: Bees and their role in forest Livelihoods. A Guide to the Services Provided by Bees and the Sustainable Harvesting, Processing and Marketing of their Products. Rome, Italy.

58. Nuru A, Admasu A, Dereje W (2001) Pollen Spectrum of Honeys and Honeybee Floral Calander of West Shoa.Addis Ababa, Ethiopia.

59. Desalegn B (2015) Honeybee Diseases and Pests Research Progress in Ethiopia-A review. African Journal of Insect, 3(1): 093-096.

60. EARO (2000) Ethiopian Agricultural Research Organization: Apiculture Research Strategy. Animal Science Research Directorate, Ethiopia, p. 30-42.

61. CSA (2011/12) Central Statistical Agency: Agricultural Sample Survey 2010/11. Report on Livestock and Livestock Characteristics, Addis Ababa, FDRE, Ethiopia.

62. Workneh A, Ranjitha P (2011) Beekeeping Sub Sector Challenges and Constraints in Atsbi Wemberta District of Eastern Zone, Tigray Region, Ethiopia. Journal of Agricultural Extension and Rural Development, 3(1): 8-12.

63. Chala K, Taye T, Kebede D, Tadele T (2012) Opportunities and Challenges of Honey Production in Gomma District of Jimma Zone, South-west Ethiopia. Journal of Agricultural Extension and Rural Development, 4(4): 85-91.

64. Assemu T, Kerealem E, Adebabay K (2013) Assessment of Current Beekeeping Management Practice and Honey Bee Floras of Western Amhara, Ethiopia. International Journal of Agriculture and Biosciences, 2(5): 196-201.

65. OIE (2017) World Organisation for Animal Health: Terrestrial Animal Health Code $\left(26^{\text {th }}\right.$ edn), Paris, France, pp. 529-527. 
66. Amsalu B, Desalegn B (2008) Study on the Ecological Distribution of Small Hive Beetles in Maize and Coffee Growing Areas. HBRC, Ethiopia.

67. Coffey F, Mary M (2007) Parasites of honeybee. Teagasc, Crops, Research Center, Oak park, Crlowcofinanced by the department of Agriculture, Fisheries and Food Ireland, p: 12-37.

68. Gizachew G, Sefinew A, Amssalu B, Malede B (2013) Prevalence and Associated Risk Factors of Bee Lice in Holeta and its Surroundings, Ethiopia. Journal Veterinary Science Technology, 4: 130.

69. Adeday G, Shiferaw M, Abebe F (2012) Prevalence of Bee lice Braulacoeca (Diptera: Braulidae) and Other Perceived Constraints to Honeybee Production in WukroWoreda, Tigray Region, Ethiopia. Journal of Global Veterinaria, 8(6): 631-635.

70. Desalegn B (2001) Some Major Pests and Predators of Honeybees in Ethiopia. Published in $3^{\text {rd }}$ Proceedings National Conference of Ethiopian Beekeeping Association. Addis Ababa, Ethiopia, p. 59-67.

71. Amsalu B, Alemayehu G, Gemechis L, Kibebew W (2010) Diagnostic Survey of Honeybee Diseases and Pests in Ethiopia. Annual Report of Holeta Research Center.

72. Amsalu B, Desalegn B (1999) Developing ant protection methods and assessing their performances: Published in the 1st Proceedings of National Conference of Ethiopian Beekeeping Association. Addis Ababa, Ethiopia, p. 83-89.

73. Tesfaye $H$ (2014) Honeybee Diseases, Pest and their Economic Importance in Ethiopia.International Journal of Innovation and Scientific Research, 10(2): 527-535.

74. Desalegn B (2007) Assessment of the Effect of Ant (Dorylusfulvus) on Honeybee Colony (Apismellifera) and their Products in West and South-West Shoa Zones, Ethiopia. Ethiopian Journal of Animal Production, 7(1): 12-26.

75. Amsalu B, Desalegn B (2001) Survey of Honeybee Pest and Pathogens in South and Southwest Parts of Ethiopia. Published in $16^{\text {th }}$ Proceedings of Ethiopian Veterinary Association, p. 86-93.

76. Etsay K, Ayalew K (2001) Survey on Honeybee Diseases and Pests in Tigray. Bureau of Agriculture and National Resources (BOANR), Mekelle, Ethiopia.

77. Mahmoud A, EL-Kazafy T (2012) Bee-Eating Birds (Coraciiformes: Meropidae) Reduce Virgin Honey Bee Queen Survival during Mating Flights and Foraging Activity of Honey Bees (ApismelliferaLithorea) Journal of International Journal of Scientific and Engineering Research, 3: 6 .

78. Lepage D (2016) Bird Check List of the World, Ethiopia.

79. Hilary F (2001) Family Meropidae (Bee-eaters). In delHoyo, Josep; Elliott, Andrew; Sargatal, Jordi. Handbook of the Birds of the World. Volume 6, Mouse birds to Hornbills. Barcelona: Lynx Edicions, pp. 286-325.

80. Aster Y, Amsalu B, Betre Y, Desalegn B, Yosef S, et al. (2010) Ecological Distribution of Honeybee Chalkbrood Disease (Ascosphaeraapis) in Ethiopia. Ethiopia Journal of Animal Production, 9(1): 177-191.

81. Encyclopedia Britannica (2018) Beeswax.
82. Desalegn B, Yosef K (2005) Survey of Honeybee Pests and Pathogens in Addis Ababa. Published in $5^{\text {th }}$ Proceedings National Conference of Ethiopian Beekeeping Association. Addis Ababa, Ethiopia.

83. Aster Y, Amsalu B, Betre Y, Desalegn B, Yosef S, et al. (2007) Study on Disease of Honeybees with the Emphasis on Ecology of Chalkbrood Disease in Ethiopia. Published in Proceedings of Agricultural Research Projects Completion Workshop, IEAR, Addis Ababa, Ethiopia, pp. 18207.

84. Amssalu B, Desalegn B (2005) Distribution of Honeybee (Apismellifera Lithorea) Nosema (Nosemaapis) in Ethiopia. Published in 4th Proceedings of Ethiopian Beekeepers Association. Addis Ababa, Ethiopia, p. 19-26.

85. Desalegn B (2014) Occurrences and Distributions of Varroa Mite (Varroa destructor) in Tigray regional State, Ethiopian Journal of Fisheries and Livestock Production, 2: 1-4.

86. Abiyu Z (2011) An Assessment of Factors that Affect Development of Beekeeping in Rural Areas: in Case of Hurumu district, Ilubabor zone, Oromia regional state, Ethiopia. Msc thesis Addis Abeba University, Ethiopia, pp. 1- 107.

87. Nuru A (2002) Geographical Races of Honeybees (Apismellifera) of the Northern Regions of Ethiopia. PhD dissertation, Rhodes University, Department of Zoology and Entomology, South Africa, P. 265.

88. Kerealem E, Tilahun G, Preston T (2005) Constraints and Prospects for Apiculture Research and Development in Amhara region, Ethiopia. Andassa Livestock Research Center, Bahir Dar, Ethiopia, p. 14.

89. Awraris G, Yemisrach G, Dejen A, Nuru A, Gebeyehu G, et al. (2012) Honey Production Systems (Apismellifera Lithorea) in Kaffa, Sheka and Bench-Maji Zones of Ethiopia. Journal of Agricultural Extension and Rural Development, 4(19): 528-541.

90. Melaku G, Shifa B, Azage T, Negatu A, Lulseged B (2008) Approaches, Methods and Processes for Innovative Apiculture Development: Experiences from Ada'a-LibenWoreda, Oromia Regional State, Ethiopia.

91. Kerealem E (2005) Honeybee Production System, Opportunities and Challenges in EnebseSarMidirWoreda (Amhara Region) and Amaro Special Wereda (Southern Nations, Nationalities and Peoples Regional state), Ethiopia. M. Sc. thesis, Alemaya University, Ethiopia, pp. 133.

92. Gidey Y, Bethlehem K, Dawit K, Alem M (2012) Assessment of Beekeeping Practices in AsgedeTsimbla District, Northern Ethiopia: Absconding, Bee Forages and Bee Pests. Mekele, Ethiopia. African Journal of Agricultural Research, 7(1): 1-5.

93. Abebe A (2009) Market Chain Analysis of Honey Production in Atsbi Wemberta District, Eastern Zone of Tigray National Regional State. Department of Agricultural Economics, School of Graduate Studies, Haramaya University, Ethiopia

94. Central Statistical Agency (2013) Agricultural Sample Survey. Livestock and Livestock Characteristics, Statistical Bulletin 570. Central Statistical Authority, Addis Ababa, Ethiopia.

95. Haftu K, Gezu T (2014) Survey on Honey Production System, Challenges and Opportunities in Selected Areas of Hadya Zone, Ethiopia, Journal of Agricultural Biotechnology and Sustainable Development, 6(6): 60-66. 
This work is licensed under Creative Commons Attribution 4.0 License

DOI: 10.19080/JDVS.2018.08.555743

\section{Your next submission with Juniper Publishers}

will reach you the below assets

- Quality Editorial service

- Swift Peer Review

- Reprints availability

- E-prints Service

- Manuscript Podcast for convenient understanding

- Global attainment for your research

- Manuscript accessibility in different formats

( Pdf, E-pub, Full Text, Audio)

- Unceasing customer service

Track the below URL for one-step submission https://juniperpublishers.com/online-submission.php 